\title{
THE EFFECT OF SELF REGULATED LEARNING AND SELF EFFICACY ON STUDENTS' LEARNING OUTCOMES IN ARCHIVE SUBJECT AT SMK NEGERI 10 SURABAYA
}

\author{
Lailatul Fitriyah $^{1}$, Durinda Puspasari ${ }^{2}$ \\ 1,2 Universitas Negeri Surabaya, Indonesia \\ ${ }^{1}$ lailatul.17080314029@mhs.unesa.ac.id, ${ }^{2}$ durindapuspasari@unesa.ac.id
}

\begin{abstract}
The study aimed to analyze : 1) the effect of self-regulated learning on students' learning outcomes in archive subjects at SMK Negeri 10 Surabaya; 2) the effect of self-efficacy on students' learning outcomes in archive subjects at SMK Negeri 10 Surabaya; 3) the effect of self-regulated learning and self-efficacy on student' learning outcomes in archive subjects at SMK Negeri 10 Surabaya. This type of this study was a quantitative research. Data were collected through questionnaires and interviews. The population were all students at class X OTKP for as many as 108. The samples of this study were 85 students which were selected proportional random sampling. The instrument of this study was validity test and reliability test. Then, the data were analyzed through: 1) classical assumption test consisting of normality test, multicollinearity test, and heteroscedasticity test; 2) hypothesis te sting using multiple linear regression. The results showed that: 1) there was a significant effect of self-regulated learning on student' learning outcomes in archive subject at SMK Negeri 10 Surabaya; 2) there was a significant effect of self-efficacy on student'learning outcomes in archive subject at SMK Negeri 10 Surabaya; 3) there was a significant effect of self-regulated learning and self-efficacy on students' learning outcomes in archive subject at SMK Negeri 10 Surabaya.
\end{abstract}

Keywords: self regulated learning, self efficacy, learning outcomes

\section{PENGARUH SELF REGULATED LEARNING DAN SELF EFFICACY TERHADAP HASIL BELAJAR SISWA PADA MATA PELAJARAN KEARSIPAN DI SMK NEGERI 10 SURABAYA}

\begin{abstract}
ABSTRAK
Tujuan penelitian ini untuk mengetahui : 1) pengaruh self regulated learning terhadap hasil belajar siswa pada mata pelajaran kearsipan di SMK Negeri 10 Surabaya; 2) pengaruh self efficacy terhadap hasil belajar siswa pada mata pelajaran kearsipan di SMK Negeri 10 Surabaya; 3) pengaruh self regulated learning dan self efficacy terhadap hasil belajar siswa pada mata pelajaran kearsipan di SMK Negeri 10 Surabaya. Jenis Penelitian ini merupakan penelitian kuantitatif. Teknik pengumpulan data menggunakan angket dan wawancara. Populasi yang digunakan seluruh siswa kelas $\mathrm{X}$ OTKP berjumlah 108. Sampel penelitian ini adalah 85 siswa dengan menggunakan propotional random sampling. Uji coba instrumen penelitian ini yaitu uji validitas dan uji reliabilitas. Teknik analisis data yang digunakan yaitu: 1) uji asumsi klasik yang terdiri dari uji normalitas, uji multikolinieritas, dan uji heteroskedastisitas; 2) uji hipotesis menggunakan regresi linier berganda. Hasil penelitian menunjukkan bahwa: 1) terdapat pengaruh signifikan self regulated learning terhadap hasil belajar siswa pada mata pelajaran kearsipan di SMK Negeri 10 Surabaya; 2) terdapat pengaruh signifikan self efficacy terhadap hasil belajar siswa pada mata pelajaran kearsipan di SMK Negeri 10 Surabaya; 3) terdapat pengaruh signifikan self regulated learning dan self efficacy terhadap hasil belajar siswa pada mata pelajaran kearsipan di SMK Negeri 10 Surabaya.
\end{abstract}

Kata Kunci: self regulated learning, self efficacy, hasil belajar

\begin{tabular}{|c|c|c|}
\hline Submitted & Accepted & Published \\
\hline 14 Mei 2021 & 09 Agustus 2021 & 16 September 2021 \\
\hline
\end{tabular}

\begin{tabular}{|l|l|r|}
\hline Citation & $:$ & $\begin{array}{r}\text { Fitriyah, L., \& Puspasari, D. (2021). The Effect of Self Regulated Learning and Self Efficacy on Students' Learning } \\
\text { Outcomes in Archive Subject at SMK Negeri 10 Surabaya. Jurnal PAJAR (Pendidikan dan Pengajaran), 5(5), } \\
1321-1338 . \text { DOI : http://dx.doi.org/10.33578/pjr.v5i5.8414. }\end{array}$ \\
\hline
\end{tabular}

\section{PENDAHULUAN}

Pendidikan yaitu suatu peristiwa sangat diperlukan bagi semua manuasia, sehingga dengan adanya pendidikan manusia bisa berkembang baik dari segi pengetahuan maupun keterampilan.
Pendidikan mempunyai tujuan agar bisa meningkatkan keterampilan, pengetahuan, serta perilaku siswa agar bisa mengembangkan potensi yang dimilikinya untuk berkehidupan 
dimasyarakat. Menurut Undang-undang No. 20 tahun 2003 tentang Sistem Pendidikan Nasional, pendidikan adalah usaha sadar dan terencana untuk mewujudkan suasana belajar dan proses pembelajaran agar siswa secara aktif mengembangkan potensi dirinya untuk memiliki kekuatan spiritual keagamaan, pengendalian diri, kepribadian, kecerdasan, akhlak mulia, serta keterampilan yang diperlukan dirinya, masyarakat, bangsa dan negara. Pendidikan adalah dimana siswa dalam proses belajar yang nantinya bisa memperoleh tujuan yang ada pada kehidupannya. Permana \& Latifah (2015) berpendapat bahwa di dalam pendidikan sendiri terdapat salah satu parameter yang dapat dihitung untuk meningkatkan berhasilnya suatu pendidikan yang nantinya bisa melalui hasil belajarnya siswa. hasil belajar siswa yaitu hasil feedback untuk siswa ketika pembelajaran berlangsung dari guru, dan dibutuhkan disetiap jenjang pendidikan tanpa terkecuali salah satunya yaitu pada jenjang SMK.

Gunawan, Nuridja, \& Suharsono (2014), bahwa SMK adalah sebuah pendidikan yang ada pada jenjang menengah bisa mempersiapkan lulusan agar bisa menjadi tenaga yang kreatif, terampil, serta produktif, dan bisa meningkatkan sikap profesionalitas dibidangnya tertentu. SMK Negeri 10 Surabaya yaitu salah satu sekolah sudah berkreditasi "A $A$ " dan mempunyai beberapa jurusan yaitu Multimedia, Usaha Perjalanan Wisata, Pemasaran, Perbankan, Akuntansi, Farmasi, dan Otomatisasi dan Tata Kelola Perkantoran (OTKP). Mata pelajaran kearsipan merupakan mata pelajaran produktif dijurusan OTKP yang wajib ditempuh pada siswa kelas X. Pelajaran kearsipan ini penting untuk dipelajari karena siswa diharapkan mampu menguasai pengetahuan maupun keterampilan yang berkaitan dengan arsip dan kearsipan, penggunaan peralatan kearsipan, penanganan surat masuk dan keluar, klasifikasi dan indeks arsip, menyimpan arsip, penggunaan serta pemeliharaan arsip, retensi arsip, dan penyusutan arsip, sehingga diharapkan siswa dapat mengaplikasikan pada saat bekerja nantinya. SMK Negeri 10 Surabaya menetapkan KKM 70 pada mata pelajaran kearsipan untuk hasil belajar siswa. Menurut Puspasari \& Puspasari (2019), dalam hal ini diperlukan adanya kompetensi yang dimiliki oleh pendidik melalui penyampaian materi pelajaran dengan baik sehingga diharapkan mampu membimbing peserta didik untuk belajar mandiri melalui berbagai sumber belajar yang diterapkan di dalam proses pembelajaran.

Hasil belajar dipakai untuk mengukur agar bisa mencapai tujuan belajar, sehingga bisa diperlukan sebagai proses yang memahami apakah hasil belajar dapat sesuai dalam tujuan pembelajaran (Yulianto, 2019). Apabila hasil belajar siswa bagus, maka siswa bisa memperoleh kriteria yang sudah ditentukan pihak sekolah, namun apabila hasil belajar siswa kurang baik maka siswa belum mencapai kriteria yang sudah ditentukan pihak sekolah. Sependapat dengan Permana \& Latifah (2015) mengungkapkan bahwasannya proses belajar dapat berhasil membuktikan bahwa hasil belajar bisa maksimal, sedangkan proses belajar tidak dapat berhasil maka membuktikan hasil belajar rendah. Sehingga hasil belajar siswa menjadikan feedback untuk mengukur kopetensi siswa. Masing masing siswa pasti mempunyai kelebihan serta memiliki cara belajar dengan berbeda - beda dalam mencapai hasil belajarnya. Oleh karena itu diakibatkan faktor internal dan eksternal. Faktor internal merupakan cara siswa dalam mengatur belajar (self regulated learning), sedangkan faktor eksternal yang berarti efikasi diri (self efficacy). Hasil belajar siswa dapat memperoleh disekolah untuk mengukur tingkat berhasilnya siswa untuk mencerna materi pembelajaran telah diberikan oleh pendidik. Monika \& Adman (2017) berpendapat bahwa hasil belajar merupakan upaya siswa dalam memperkirakan sejauh mana siswa tersebut dalam memperhatikan belajarnya. Sehingga dimaknai bahwa mempunyai hasil belajar yang bagus merupakan siswa bisa memperoleh materi belajar yang telah diberikan guru.

Faktor internal yang bisa mempengaruhi pada hasil belajar salah satunya adalah self regulated learning. Menurut Indrayanto (2018), merupakan kekuatan dimana siswa yang aktif bisa berencana mengontrol proses kognitif, motivasi (nilai, keyakinan, serta kondisi emosi) dan perilaku dapat mengapai tujuan yang sudah disepakati. Sejalan dengan pendapat Hamonangan 
\& Widyarto (2019) yang menyatakan bahwa self regulated learning kemampuan siswa dalam memperhatikan dirinya untuk proses belajar yang mengikut-sertakan afeksi, kognisi, serta perilaku siswa untuk memperoleh tujuan belajar. Sehingga self regulated learning menjadikan siswa bisa mengatur serta menilai dirinya dengan terstruktur agar memperoleh tujuan belajanya dan dapat meningkatkan hasil belajar yang maksimal, bisa serasi dengan kemampuan dalam dirinya. Riset ini didukung oleh Permana \& Latifah (2015) yang menyatakan bahwa self regulated learning mempengaruhi hasil belajar pengantar akuntansi secara positif dan signifikan. Penelitian Astutik \& Wasiti (2016) menjelaskan bahwa variabel self regulated learning berpengaruh yang signifikan pada hasil belajarnya siswa. Hasil penelitian yang dilakukan Sucipto (2014) juga menyimpulkan self regulated learning ada pengaruh dengan hasil belajar siswa pada pelajaran ekonomi.

Adapun faktor eksternal yang bisa berpengaruh pada hasil belajar salah satunya yaitu self efficacy. Menurut Handayani (2020), self efficacy adalah sebuah wujud kepercayaan dalam kekuatan melakukan tugas sehingga dapat memperoleh tujuan. Apabila siswa mempunyai self efficacy dia akan berhasil memperoleh tujuan belajarnya serta bisa melewati ketika mengahadapi kesulitan. baik dalam memahami materi maupun tugas yang diberikan guru. Self efficacy yang dimiliki siswa tinggi dia akan mempercayai bahwa dia bisa mengerjakan sesuatu yang menggapai kemampuannya sedangkan siswa yang memiliki self efficay rendah tidak mempunyai presepsi bahwa dia tidak bisa melakukan semua tugas telah diberikan guru untuk kegiatan pembelajaran. Hal tersebut senada oleh penelitian Rosyida, Utaya, \& Budijanto (2016) yang mengungkapkan self efficacy yaitu keyakinan yang dimiliki oleh siswa dalam kemampuannya agar bisa berhasil memperoleh tujuan. Self efficacy mengasikan dorongan kepada siswa untuk berusaha, sehingga bisa dinyatakan bahwa berhasilnya siswa itu sendiri dipengaruhi oleh self efficacy. Hal tersebut sesuai oleh penelitian Monika \& Adman (2017) yang menjelaskan ada korelasi yang memperkuat self efficacy dengan hasil belajar siswa. Penelitian
Respita (2020) yang menjelaskan bahwasannya self efficacy ada pengaruh signifikan pada hasil belajar siswa. Penelitian Annisa (2017) juga mengutarakan variabel self efficacy secara signifikan mempengaruhi hasil belajar siswa.

Berdasarkan wawancara oleh guru mata pelajaran kearsipan di SMK Negeri 10 Surabaya bahwasanya self regulated learning yang ada pada siswa masih kurang terlihat dari siswa yang kurang mengatur diri dalam kegiatan belajar pada saat mengikuti mata pelajaran kearsipan, pengaturan dan cara belajar sebagian siswa kelas X OTKP masih belum baik. Hal ini ditunjukkan dengan sebagian siswa yang saat memperoleh proses belajar terlihat cenderung pasif serta sebagian siswa juga masih terlambat dalam peyelesaian tugas. Terdapat beberapa siswa dalam mempunyai self-efficacy rendah bahwa dirinya tidal percaya diri akan kempunan yang dimilikinya untuk menghadapi tntangan belajay untuk dialami, bisa ditandai dengan siswa merasa kurang percaya diri dan yakin dalam mengerjakan soal Ulangan Harian (UH) maupun Ulangan Tengah Semester (UTS), pada saat siswa diberikan tugas oleh guru mengenai pembelajaran kearsipan mengenai materi praktik masih ada beberapa siswa yang mencotek hasil pekerjaan temannya, dan pada saat guru memerintahkan siswa untuk memaparkan hasil pekerjaanya sebagian besar siswa belum percaya diri akan hasil pekerjaannya.

Untuk itu menanamkan self regulated learning dan self efficacy siswa menjadikan sebuah kewajiban untuk mata pelajaran kearsipan agar dapat mendorong siswa, agar siswa bisa lebih aktif serta percaya diri atas kekuatannya untuk belajar yang nantinya bisa memperkuat tercapainya tujuan belajar dan mendapatkan hasil belajar yang lebih optimal. Maka diharapkan, siswa pada self regulated learning bisa mengatur dirinya untuk pembelajaran dan memiliki self efficacy tinggi sehingga bisa menumbuhkan hasil belajar pada mata pelajaran kearsipan. Penelitian ini bertujuan untuk menganalisis: 1) pengaruh self regulated learning terhadap hasil belajar siswa pada mata pelajaran kearsipan di SMK Negeri 10 Surabaya; 2) pengaruh self efficacy terhadap hasil belajar siswa pada mata pelajaran kearsipan di SMK Negeri 10 Surabaya; 3) pengaruh self 
regulated learning dan self efficacy terhadap hasil belajar siswa pada mata pelajaran kearsipan di SMK Negeri 10 Surabaya.

\section{KAJIAN TEORETIS Belajar}

Belajar merupakan kegiatan siswa yang mendapatkan perilaku, pengetahuan, serta keterampilan dengan mengembangkan perangkat pembelajaran (Komaro, 2014). Menurut Puspitasari \& Margunani (2017), belajar yaitu proses merubah kepada tahap yang lebih baik lagi, oleh sebab itu, diharapkan sekolah bisa mengamati serta bisa mengukur sejauh mana proses belajar nantinya akan menghasilkan hasil belajar yang dijadikan suatu acuan dalam kesuksesan belajar dan mengajar tersebut. Astutik \& Wasiti (2016) mengartikan belajar sebagai upaya bisa dijalankan oleh siswa yang memperoleh hasil serta mendapatkan perubahan perilaku yang berdasarkan atas pengalaman yang dijalaninya. Menurut Wilanda \& Supriyono (2014), belajar adalah usaha pengembangan diri dengan hasil perubahan perilaku seseorang yang awalnya tidak mengetahui menjadi lebih tahu dan menjadi lebih baik lagi. Pane \& Dasopang (2017) berpendapat bahwa belajar yaitu sebuah sistem dimuat pada proses pendidikan, serta pendidikan terbagi menjadi beberapa kompoen akan terbubung satu sama lain, antara lain modul, guru, siswa, tujuan, media, tata cara, dan penilaian. Arfani (2016) dalam penelitiannya juga mengemukakan bahwa belajar yaitu bagian dari pendidikan yang berkaitan dengan tujuan interaksi, baik secara eksplisit maupun implisit. Dalam mengungkapkan isi dan pesan belajar sehingga dalam belajar siswa bisa memperoleh kemampuannya yang terdiri dari tiga rana yaitu kognitif, afektif dan psikomotor.

Sehingga dari beberapa peneliti sehingga disimpulkan bahwasannya belajar yaitu sebuah proses atau kegiatan dilakukan agar mendapatkan ilmu pengetahuan, perubahan perilaku ataupun cara berpikir dengan interaksi secara langsung agar menjadi lebih baik lagi dan memperoleh hasil yang didasarkan pada pengalaman yang pernah dialaminya.

\section{Pembelajaran}

Pembelajaran merupakan sebuah interaksi anatara guru serta siswa dan sumber belajar. Pembelajaran juga untuk bantuan siswa agar bisa mewujudkan proses pengetahuan, serta perolehan ilmu, penguasaan kemahiran, tabiat, dan membentukan sikap percaya diri pada siswa (Komaro, 2014). Dalam pembelajaran diperlukan beberapa komponen saat proses pembelajaran agar terlaksana dengan baik anata lain media, materi, ujian, metode, evaluasi, guru dan siswa (Pane \& Dasopang, 2017). Oleh sebab itu komponen dalam pembelajaran tersebut saling berhubungan, sehingga apabila salah satu diantara komponen tersebut tidak digunakan maka akan mempengaruhi proses pembelajaran. Menurut Anurrahman (2014), pembelajaran yaitu pemberian masukan kepada siswa tidak terdidik menjadikan siswa lebih terdidik, serta siswa yang tidak mempunyai pengetahuan menjadikan siswa bisa mempunyai penegtahuan, dan siswa dengan sikap tidak melihatkan dirinya positif menjadi siswa yang bersikap dan memiliki tingkah laku yang lebih baik. Pembelajaran bisa dikategorikan baik atau bisa berhasil jika tujuan pembelajaran dapat tercapai. Ketercapaian tersebut apabila tujuan pembelajarannya bisa dipaparkan dari hasil belajar yang baik (Rosyida, Utaya, \& Budijanto, 2016). Hal ini juga dikemukakan oleh pendapat Arfani (2016) mengungkapkan bahwa pembelajaran adalah proses pendidikan yang bisa membuat siswa bisa belajar dengan kebutuhan yang diinginkannya. Karena disini guru mempunyai peran fasilitator sebagai fasilitas dan mewujudkan situasi membantu untuk meningkatkan kemampuan belajar siswa.

Sehingga dari beberapa pendapat tersebut dapat disumpulkan pembelajaran yang berarti berinteraksi yang terjadi antara guru serta siswa dan sumber belajar dengan tujuan untuk memperoleh suatu perubahan perilaku, dan pembelajaran juga bertujuan untuk mengubah peserta didik yang belum terdidik menjadi terdidik, berpengetahuan, serta memiliki sikap dan perilaku lebih positif. 


\section{Hasil Belajar}

Hasil belajar dijadikan sebagai kriteria mencapai tujuan pendidikan. Sependapat dengan Purwanto (2009) menjelaskan bahwasannya hasil belajar adalah realisasi untuk bisa mencapai tujuan pendidikannya agar hasil belajar telah dicapai tergantung pada tujuan pendidikan. Sejalan dengan pendapat Sucipto (2014) yang mengungkapkan bahwa hasil belajar yaitu sebuah akhir dari penilaian proses serta pengenalan dilaksanakan secara berulang kali, dan bisa tersimpan dalam jangka waktu tidak bisa dipungkiri oleh sebab itu hasil belajar aka bisa menjadikan pribadi siswa ingin menggapai hasil belajar yang lebih bagus, oleh karena itu hasil belajar akan membawa perbuatan yang sebelum melaksanakan proses belajar yang sesuai dengan tujuan pendidikkannya. Menurut Indrayanto (2018), hasil belajar yaitu dapat memperoleh setelah melakukan kegiatan belajar dan bisa mengukur langsung menggunakan alat tes. Wilanda \& Supriyono (2014) berpendapat bahwa hasil belajar meningkatkan penguasaan yang diperoleh siswa pada saat menjalankan program belajar sesuai tujuan pendidikan sudah disepakati. Tercapainya hasil belajar siswa memperoleh melalui tes, ulangan harian, maupun ujian, jadi bahwa siswa memperoleh hasil belajar yang baik dapat diketahui dari siswa tidak bisa mencapai ketentuan yang dudah ditentukan pihak sekolah (Puspitasari \& Margunani, 2017). Menurut Sihaloho, Rahayu, \& Wibowo (2018), hasil belajar yaitu hasil yang telah didapatkan siswa sesudah menjelankan interaksi belajarnya dan mengajar yang terdiri dari kognitif (pengetahuan), afektif (sikap), dan psikomotor (keterampilan).

Sehingga dapat disimpulkan bahwa hasil belajar adalah suatu perubahan dimiliki oleh siswa sesudah mendapatkan proses belajar. Hasil belajar akan dapat membentuk siswa menjadi lebih baik agar bisa memberikan perubahan tingkah laku siswa sesudah mengikuti pembelajaran. Hasil belajar bisa meningkatkan perkembangan mental siswa yang lebih baik. Hasil belajar pada penelitian ini didapatkan dari nilai UTS Semester Ganjil Tahun Ajaran 2020/2021 pada Mata Pelajaran Kearsipan Kelas X OTKP.

\section{Self Regulated Learning}

Self regulated learning yaitu individu mempunyai kekuatan yang yang bisa memeriksa proses perilaku, motivasi, dan kognitif agar bisa tercapainya tujuan yang talah diterapkan. Sebab itu jika self regulated learning semakin baik sehingga akan semakin baik juga hasil belajar yang dicapai sedangkan self regulated learning dimiliki rendah akan berkurang untuk melaksanakan pemantauan, evaluasi, perencanaan, dan pembelajaran, yang nantinya hasil belajar tidak bejalan dengan maksimal (Sucipti, 2014). Menurut Astutik \& Wasiti (2016), self regulated learning adalah pengaturan hal-hal yang berkaitan dengan usaha sadar siswa dengan belajar secara mandiri. Siswa dapat mewujudkan keberhasilan belajarnya dengan mengatur dirinya dengan belajar yang baik, jika siswa bisa mengolah cara belajarnya sehingga akan mencapai tujuan akan dicapainya. Permana \& Latifah (2015) mengungkapkan bahwa proses self regulated learning, peserta didik bisa mengatur tujuan pembelajaran mereka, mengavaluasi hasil belajar mereka, membuat rancangan pembelajaran mereka dan bisa menekankan gangguan sehingga peserta didik diharapkan bisa meningkatkan hasil belajar mereka dengan baik. Menurut Fasikhah \& Fatimah (2013), self regulated learning adalah siswa yang aktif dalam mengatur proses belajarnya secara mandiri, dari memantau, merencanakan, mengontrol, dan mengevaluasi dirinya secara teratur agar tercapainya tujuan dalam belajarnya, dengan melaksanakan strategi kognitif, behavioral dan motivasional. Sedangkan menurut Situmorang, Hutasuhut, \& Maipita (2019), self regulated learning is a series of a person's ability to organize learning activities that include planning, implementing, evaluating learning in cognitive, affective and psychomotor aspects, yang diartikan bahwa self regulated learning merupakan rangkaian dari kemampuan seseorang sebagai pengatur kegiatan belajar mereka yang meliputi, perencanaan, pelaksanaan, evaluasi pembelajaran pada aspek kognitif, afektif, dan psikomotor.

Dapat disimpulkan bahwa self regulated learning yaitu siswa yang memiliki kemampuan secara mandiri yang mampu mencapai tujuan yang 
telah diinginkan. Oleh karena itu jika self regulated learning yang dimiliki siswa tinggi maka hasilnya bisa berhasil dengan optimal, begitu kebalikannya jika self regulated learning yang dimiliki sisiwa rendah sehingga hasilnya belum bisa optimal. Menurut Reynold \& Miller (2013), indikator self regulated learning untuk penelitian ini yaitu: 1) self evaluating yaitu memeriksa pekerjaan untuk memastikannya benar; 2) organizing and transforming yaitu membuat garis besar sebelum menulis; 3) goal setting ang planning yaitu belajar terlebih dahulu di jauh hari sebelum ujian; 4) seeking information yaitu melakukan penelitian pustaka sebelum menulis makalah; 5) keeping records and monitoring merupakan upaya diprakarsai siswa sebagai pencatat peristiwa atau hasil; 6) environmental structuring yaitu upaya yang dimulai siswa untuk mengatur pengaturan fisik untuk membuat pelajaran lebih mudah; 7) self consequating yaitu menghargai diri sendiri setelah mendapatkan nilai ujian yang bagus; 8) rehearsing and memorizing yaitu menghafal materi dengan latihan terang-terangan; 9) seeking peer asisstance yaitu meminta bantuan teman; 10) seeking teacher assistance yaitu meminta bantuan guru.

\section{Self Efficacy}

Self efficacy adalah keyakinan pada seorang siswa terhadap kopetensinya sebagai pelaksanaan kegiatan untuk mencgapai suatu tujuan dimana siswa akan mampu menangggapi segala tantangan serta bisa memperkiarakan seberapa jauh usaha yang diperlukan dalam mencapai tujuan tertentu agar usahanya bisa dilakukan dengan berhasil (Fitria \& Handayani, 2020). Menurut Yulianto (2019), self efficacy pada diri siswa begitu penting karena bisa mencapai tujuan hasil belajar siswa. Tetapi sebenarmya self efficacy yang dipegang siswa masi rendah disebabkan tidak percaya diri dan yakin bahwa kemampuannya sendiri untuk menghadapi dalam tantangan belajarnya. Suherman, Purwaningsih, \& Diana (2018) berpendapat bahwa self efficacy dapat mempengaruhi pemilihan bagaimana cara siswa dalam memecahkan sebuah masalah dalam soal, melakukan tingkat usaha dalam melakukan proses pembelajaran, dan kegigihan pada saat menghadapi kesulitan dalam pembelajaran. Menurut Sihaloho, Rahayu, \& Wibowo (2018), self efficacy berpacu dalam meyakinkan siswa pada kemampuannya yang dapat berhasil melakukan tugasnya, mengendalikan masalah, dan bisa mengerjakan tindakan diperlukan sebagai pencapaian tugas tersebut. Seorang siswa mempunyai self efficacy bahwa siswa tersebut untuk memotivasi supaya berhasil untuk mencapai tujuan belajar dan bisa bertahan ketika menangani suatu kesulitan dalam belajarnya (Wahyuningtyas \& Febrianingsih, 2018)

Berdasarkan penjelasan diatas menurut para ahlis dapat disimpulkan bahwa self efficacy yaitu seorang individu yang memiliki kemampuan agar mencapai tujuan dimana siwa bisa menghadapi berbagai macam tantangan, bisa mengatasi masalah, menyelesaikan tugas, dan melakukan tindakan yang diperlukan agar bisa dilakukan dengan berhasil. Sehingga self-efficacy diperlukan siswa agar bisa menumbuhkan hasil belajarnya. Dalam penelitian ini terdapat indikator self efficacy menurut Zimmerman (2000) dan Monika \& Adman (2017) yang terdiri dari level, generality, dan strength. Level yaitu kemampuan siswa menyelesaikan tugas yang sulit dengan berbagai macam variasi dan menetapkan perencanaan mengatur dirinya pada saat menyelesaikan tugas. Generality adalah mempunyai keyakinan dalam kempuan untuk dijadikan pengalaman yang memberikan kekuatan untuk mencapai hasil belajar yang baik dan kekuatan pada kemampuannya dalam mata pelajaran Strength merupakan kekuatan keyakinan pada kemampuan usaha untuk melancarkan tujuan belajar yang dialaminya dan mempunyai keyakinan pada kemampuannya untuk mencapai tujuan belajar. berikut :

Hipotesis untuk penelitian ini sebagai

\section{Hubungan Self Regulated Learning dengan Hasil Belajar Siswa}

Berdasarkan dari penelitian Sucipto (2014) untuk variabel self regulated learning terdapat pengaruh pada hasil belajarnya siswa. Aryani \& Hasyim (2018) menjelaskan terdapat pengaruh yang signifikan antara self regulated 
learning dengan hasil belajar matematika. Menurut Permana \& Latifah (2015), regulated learning berpengaruh terhadap hasil belajar siswa yang positif dan signifikan. Penelitian Astutik \& Wasiti (2016) menjelaskan bahwa ada pengaruh yang signifikan self regulated learning terhadap hasil belajar siwa. Penelitian yang dilakukan oleh Putra, Arini, \& Sudarma (2019) menyampaikan bahwa terdapat pengaruh yang sinifikan model pembelajaran self regulated learning dengan hasil belajar IPA Siswa. Dari beberapa penelitian diatas kemudian dijadikan sebagai refrensi untuk penelitian ini agar dapat mengetahui apakah pengaruh self regulated learning yang dimiliki siswa mampu mempengaruhi hasil belajar siswa. Sehingga dapat diperoleh hipotesis yang diajukan sebagai berikut:

$\mathrm{H}_{1}$ : Terdapat pengaruh signifikan self regulated learning terhadap hasil belajar siswa pada mata pelajaran kearsipan di SMK Negeri 10 Surabaya

\section{Hubungan Self Efficacy dengan Hasil Belajar Siswa}

Hasil penelitian dari Rustam \& Wahyuni (2020) menjelaskan bahwa mempunyai hubungan antara self efficacy dengan hasil belajar matematika siswa. Menurut Mayanto (2020), self efficacy yang dimiliki siswa berpengaruh positif pada hasil belajar pendidikan jasmani. Penelitian Rahmatika \& Susilowibowo (2016) mengemukakan Efikasi diri (Self Efficacy) mempengaruhi hasil belajar komputer akuntansi $M Y O B$. Asri, Witono, \& Affandi (2020) mengungkapkan bahwa ada pengaruh untuk variabel self efficacy dengan hasil belajarnya siswa SD. Peneliti oleh Hardianto, Erlamsyah, \& Nurfarhanah (2014) mengutarakan variabel self regulated learning mempunyai pengaruh yang signifikan pada hasil belajar siswa SMA. Berdasrkan hasil penelitian tersebut kemudian digunakan sebagai acuan dalam penelitian ini untuk dapat melihat seperti apa self efficacy siswa mampu mempengaruhi hasil belajar siswa. sehingga hipotesis penelitian diajukan sebagai berikut :
$\mathrm{H}_{2}$ : Terdapat pengaruh signifikan self efficacy terhadap hasil belajar siswa pada mata pelajaran kearsipan di SMK Negeri 10 Surabaya

\section{Hubungan Self Regulated Learning dan Self Efficacy dengan Hasil Belajar Siswa}

Berdasarkan hasil penelitian yang dilakukan oleh Meiliati, Darwis, \& Asdar (2018) menunjukkan bahwa variabel motivasi belajar, self regulated learning, dan self efficacy secara simultan berpengaruh dengan hasil belajar matematika. Menurut Tarumasely (2021), self regulated learning dan self efficacy terdapat pengaruh pada prestasi akademik mahasiswa. Altun \& Erden (2013) pada penelitiannya menjelaskan bahwasannya secara simultan ada pengaruh yang positif untuk srategi pembelajaran berbasis self regulated learning dan persepsi self efficacy terhadap prestasi akademik. Penelitian Ruliyanti \& Laksmiwati (2014) pada hasil penelitiannya juga mengutarakan bahwasannya ada hubungan antara self regulated learning dan self efficacy dengan prestasi akademik siswa. oleh karena itu dari beberapa penelitian diatas yang kemudian akan dijadikan refrensi sebagai penelitian ini agar bisa mengetahui pengaruh self regulated learning dan self efficacy mampu mempengaruhi hasil belajarnya siswa. Sebab hipotesis penelitian ini diajukan sebagai berikut : $\mathrm{H}_{3}$ : Terdapat pengaruh signifikan self regulated learning dan sel efficacy terhadap hasil belajar siswa pada mata pelajaran kearsipan di SMK Negeri 10 Surabaya

\section{METODE PENELITIAN}

Penelitian ini merupakan penelitian deskirptif dengan pendekapan kuantitatif. Teknik pengumpulan yang dipakai yaitu angket menggunakan skala likert dan wawancara untuk studi pendahuluan dengan menggunakan pedoman wawancara tidak terstruktur. Populasi yang dipakai semua siswa kelas X OTKP di SMK Negeri 10 Surabaya dengan jumlah 108. Teknik pengambilan sampel menggunakan propotional random sampling. Penentuan besarnya sampel yang dipakai pada penelitian ini menggunakan rumus Yamene Sugiyono (2019) sebagai berikut: 


$$
\begin{aligned}
& \mathrm{n}=\frac{\mathrm{N}}{1+\mathrm{N}(\mathrm{e})^{2}} \\
& \mathrm{n}=\frac{108}{1+108(5 \%)^{2}} \\
& \mathrm{n}=\frac{108}{1,27}
\end{aligned}
$$

$\mathrm{n}=85.03$

Sehingga memperoleh sampel dalam penelitian ini sebanyak 85 siswa. Perhitungan sampel oleh siswa kelas X OTKP SMK

\begin{tabular}{|c|c|c|}
\hline Kelas & Jumlah & Sampel \\
\hline X OTKP 1 & 36 Siswa & 28 \\
\hline X OTKP 2 & 36 Siswa & 28 \\
\hline X OTKP 3 & 36 Siswa & 29 \\
\hline Total & 108 Siswa & 85 \\
\hline
\end{tabular}
Negeri 10 Surabaya sebagai berikut :

Tabel 1. Perhitungan Sampel Penelitian

Adapun model konseptual penelitian ini yaitu antara lain dibawah ini :

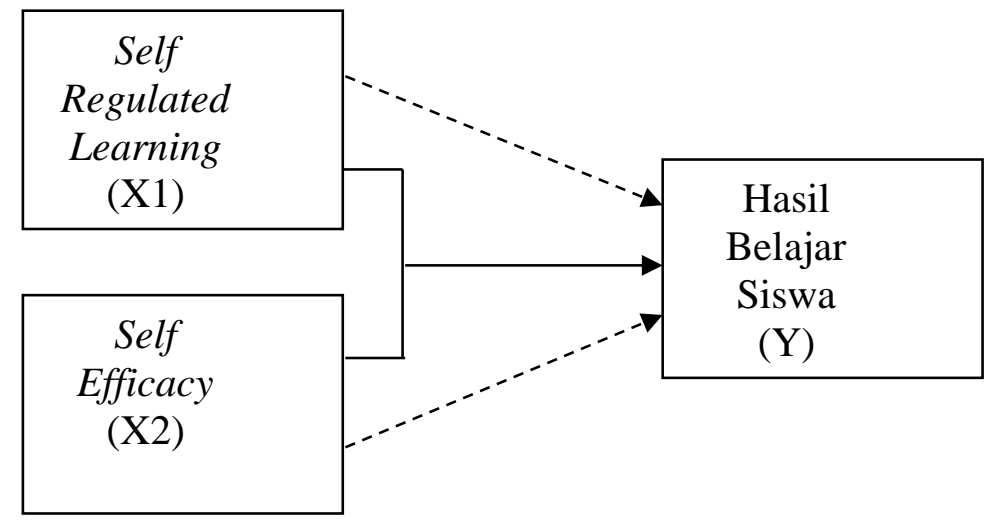

\section{Gambar 1. Model Konseptual Penelitian \\ Sumber : Data Diolah Peneliti (2021)}

Keterangan :

\begin{tabular}{ll}
$\mathrm{X} 1$ & $:$ Self Regulated Learning \\
$\mathrm{X} 2$ & $:$ Self Efficacy \\
$\mathrm{Y}$ & $:$ Hasil Belajar Siswa \\
\hline $\mathbf{Z}-\mathbf{Z}$ & : Pengaruh Secara Simultan \\
\hline
\end{tabular}

Uji coba instrumen untuk penelitian ini meliputi: 1) uji validitas, yaitu menggunakan tolak ukur sah atau dinyatakan valid tidaknya sebuah kuisoner. Kuisoner dinyatakan valid apabila pernyataan kuisoner bisa mengatakan suatu yang dapat diukur menggunakan kuisoner tersebut. Sehingga item dinyatakan valid sebab nilai $r$ hitung lebih besar dari pada nilai $r$ tabel; 2) uji reliabilitas yaitu mengukur suatu kuesioner, dimana jawaban seseorang yang bisa dikatakan reliabel pada kuisoner jika nilai cronbach alpha $>0.6$ (Ghozali, 2013).

Teknik analisis yaitu: 1) Uji Asumsi Klasik yang meliputi a) Uji Normalitas, sebagai mengetahui normal atau tidaknya data yang didapat dari responden, dilakukan melalui kolmogorov smirnov, bila model regresi dikatakan 
mencapai uji normalitas bahwa nilai signifikansi > 0.05 data tersebut dikatakan normal (Nurhasanah, 2017), b) Uji Multikolinieritas, untuk uji multikolinieritas ditentukan dari nilai VIF pada setiap variabel independen, dimana jika VIF $<10$ maka tidak terjadi multikolinieritas (Gujarati, 2012), c) Uji Heteroskedastisitas, mempunyai tujuan mengetahui apakah model regresi terdapat perbedaan variansi dari residual satu ke pengamatan lainnya (Ghozali, 2013). Ditemukan heteroskedastisitas pada scatterplot ditemukan adanya bentuk yang teratur, menyempit, melebar, dan bergelombang. Apabila tidak ditemukan gejala heteroskedastisitas maka dari variabel tersebut bersifat homoskedastisitas (Cintya \& Nugraha, 2020); 2) Uji hipotesis menggunakan Regresi Linier Berganda yang bertujuan untuk melihat ada pengaruh Self-Regulated Learning $\left(\mathrm{X}_{1}\right)$ dan Self Efficacy $\left(\mathrm{X}_{2}\right)$ terhadap hasil belajar siswa pada mata pelajaran kearsipan di SMK Negeri 10
Surabaya (Y) baik secara parsial maupun secara simultan.

\section{HASIL DAN PEMBAHASAN}

Hasil uji coba instrumen pada penelitian ini dapat dijelaskan sebagai berikut:

1) Uji Validitas

Menggunakan program aplikasi SPSS 20, terdapat 43 item pernyataan yang telah diujikan dan diolah uji validitasnya. Data diungkapkan valid karena nilai r-hitung lebih besar dari pada $\mathrm{r}$ tabel.

2) Uji Reliabilitas

Pada penelitian ini melalui program aplikasi SPSS 20, dapat dilihat pada nilai Cronbach's Alpha self regulated learning $0.958>$ 0.6 dan self efficacy $0.914>0.6$ sehingga dinyatakan reliabel.

Hasil uji asumsi klasik dapat dipaparkan sebagai berikut:

a. Uji Normalitas

Tabel 2. Hasil Uji Normalitas

\begin{tabular}{llr}
\hline \multicolumn{2}{c}{ One-Sample Kolmogorov-Smirnov Test } \\
\hline & \multicolumn{1}{c}{$\begin{array}{c}\text { Unstandardized } \\
\text { Residual }\end{array}$} \\
\hline $\mathrm{N}$ & Mean & 85 \\
Normal Parameters ${ }^{\mathrm{a}, \mathrm{b}}$ & OE-7 \\
& Std. Deviation & 7,80790441 \\
& Absolute &, 076 \\
Most Extreme Differences & Positive &, 047 \\
& Negative &,- 076 \\
Kolmogorov-Smirnov Z & &, 699 \\
Asymp. Sig. (2-tailed) & &, 712 \\
\hline
\end{tabular}

a. Test distribution is Normal.

b. Calculated from data.

Sumber: data diolah oleh peneliti (2021)

Dapat menjelaskan pada tabel 2 yang dapat dilihat nilai Asymp. Sig. (2-tailed) yaitu $0.712>0.05$ yang berarti data tersebut dinyatakan berdistribusi normal.

b. Uji Multikolinieritas
Hasil uji multikolinieritas didapatkan dengan nilai tolerance $>0.10$ dan VIF $<10$. Oleh sebab itu bisa dibuktikan dengan besarnya tolerance 0.854 artinya $>0.10$ dan nilai VIF 1.171 yang berarti $<10$. Oleh karenia itu disimpulkan 
bahwa untuk penelitian ini tidak terjadi c. Uji Heteroskedastisitas multikolinieritas atau tidak ditemukan korelasi antar variabel bebas.

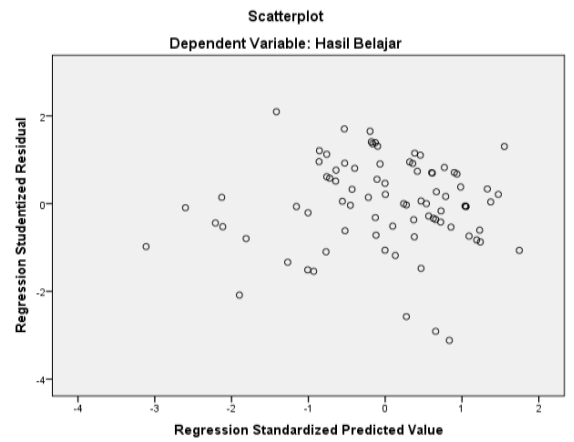

Gambar 2. Hasil Uji Heteroskedastisitas

Sumber: data diolah oleh peneliti (2021)

Bisa dilihat pada grafik scatterplot di atas yang menunjukkan bahwa tidak terjadi heteroskedastisitas dikarenakan bisa dilihat bintiknya dapat menyebar di sekitar angka 0 serta tidak menempati satu titik saja / menyebar.
Uji hipotesis penelitian ini memakai uji regresi linier berganda. dapat ditunjukkan dibawah ini :

Tabel 3. Hasil Uji-t

Coefficients $^{\mathrm{a}}$

\begin{tabular}{|c|c|c|c|c|c|}
\hline Model & \multicolumn{2}{|c|}{$\begin{array}{l}\text { Unstandardized } \\
\text { Coefficients }\end{array}$} & $\begin{array}{l}\text { Standardized } \\
\text { Coefficients } \\
\text { Beta }\end{array}$ & $\mathrm{T}$ & Sig. \\
\hline $\begin{array}{l}\text { (Constant) } \\
\text { Self }\end{array}$ & 22,169 & 7,196 & & 3,081 & ,003 \\
\hline $\begin{array}{l}\text { Regulated } \\
\text { Learning }\end{array}$ & ,265 & ,058 & ,410 & 4,546 & ,000 \\
\hline Self Efficacy & ,412 & ,098 & ,379 & 4,202 &, 000 \\
\hline
\end{tabular}

a. Dependent Variabel : Hasil Belajar

Sumber : data diolah oleh peneliti (2021)

Tabel 4. Hasil Uji-f

ANOVA ${ }^{\mathrm{a}}$

\begin{tabular}{llcc}
\hline Model & & F & Sig. \\
\hline 1 & $\begin{array}{l}\text { Regression } \\
\text { Residual } \\
\text { Total }\end{array}$ & 31,007 &, $000^{\mathrm{b}}$ \\
& & \\
\hline
\end{tabular}

Sumber: data diolah oleh peneliti (2021) 
Model persamaan regresi linier berganda untuk variabel self regulated learning dan self efficacy terhadap hasil belajar siswa pada mata pelajaran kearsipan di SMK Negeri 10 Surabaya antara lain berikut :

$Y=22.169+0.265 X_{1}+0.412 X_{2}$

1) Uji-t

Hasil Uji-t diperlukan sebagai mengetahui pengaruh variabel bebas terhadap varaibel terikat secara parsial. Hasilnya dilihat pada variabel self regulated learning $\left(\mathrm{X}_{1}\right)$ berpengaruh signifikan terhadap hasil belajar siswa dengan bernilai sig. $0.000<0.05$ artinya hipotesis pertama dapat diterima. Adapun hasil uji-t pada self efficacy $\left(\mathrm{X}_{2}\right)$ berpengaruh signifikan pada hasil belajar siswa dengan nilai sig. $0.000<0.05$ sehingga diartikan hipotesis kedua diterima juga.

2) Uji-F

Hasil uji-F untuk self regulated learning $\left(\mathrm{X}_{1}\right)$ dan self efficacy $\left(\mathrm{X}_{2}\right)$ secara simultan ada pengaruh terhadap hasil belajar siswa yang signifikan dengan nilai sig. $0.000<0.05$ sehingga dikatakan bahwa hipotesis ketiga diterima. Nilai koefisien determinasi pada kolom $R$ Square mengatakan nilai sebesar 0.431 . Hal ini berarti variabel self regulated learning dan self efficacy memberikan pengaruh terhadap hasil belajar siswa sebesar $43.1 \%$. Sedangkan $41.7 \%$ dipengaruhi variabel lain diluar penelitian ini.

\section{Pengaruh Self Regulated Learning terhadap Hasil Belajar Siswa pada Mata Pelajaran Kearsipan di SMK Negeri 10 Surabaya}

Berdasarkan hasil uji-t mengetahui nilai sig. sebesar $0.000<0.05$ yang menunjukkan bahwa $\mathrm{H}_{1}$ diterima hal tersebut yang berarti terdapat pengaruh signifikan self regulated learning terhadap hasil belajar siswa pada mata pelajaran kearsipan di SMK Negeri 10 Surabaya. Penelitian tersebut seperti diungkapkan Hamidy \& Merliza (2019) yang menjelaskan bahwa self regulated learning secara signifikan berpengaruh pada hasil belajar matematika siswa bernilai signifikansi $0.007<0.05$. Penelitian Indrayanto (2018) yang mengatakan variabel self regulated learning memiliki pengaruh positif pada hasil belajar bahasa
Arab yang signifikan dapat diketahui pada uji-t bernilai signifikan $0.000<0.05$. Penelitian Meiliati, Darwis, \& Asdar (2018) mengungkapkan bahwa self regulated learning berpengaruh positif yang pada hasil belajar matematika siswa dengan nilai sig $0.000<0.05$. Tarumasely (2020) mengutarakan bahwa dengan adanya strategi pembelajaran berbasis self regulated learning mempunyai pengaruh dengan hasil belajar yang bernilai signifikansi $0.001<0.05$. Sejalan dengan hal itu juga didukung oleh penelitian Destiasari, Warneni, \& Syahrudin (2019) yang menjelaskan bahwa self regulated learning berpengaruh positif pada hasil belajar siswa untuk nilai signifikansinya yaitu $0.000<0.05$. Namun bertentangan dengan penelitian Ranti, Budiarti, \& Trisna (2017) yang mengutarakan bahwasannya kemandirian belajar (self regulated laerning) tidak berpengaruh pada hasil belajar mahasiwa karena nilai signifikansi 0 . $570>0.05$.

Self regulated learning yang dimiliki siswa baik pada saat mengikuti pembelajaran kearsipan dan dapat memberikan pengaruh terhadap hasil belajar siswa pada mata pelajaran kearsipan di SMK Negeri 10 Surabaya. Sehingga dapat diperlihatkan dari self evaluating pada siswa, dimana siswa pada saat diberi tugas oleh guru mengenai materi kearsipan selalu memeriksa hasil pekerjaannya untuk memastikan telah mengerjakan dengan benar, selalu mengecek tugas kearsipan yang sudah dikerjakan sebelum dikumpulkan. Organizing and transforming pada siswa dapat dilihat siswa yang sudah membuat ringkasan materi kearsipan mengenai pengertian arsip sampai penyelenggaraan arsip yang disampaikan guru dapat memudahkan siswa untuk memudahkan dalam belajar. Hal ini sesuai dengan penelitian Astutik \& Wasiti (2016) menjelaskan bahwasannya belajar sebagaimana siswa untuk memperoleh hasil dan merubah tingkah laku yang mendasari atas pengalamannya. Goal setting and planning pada siswa dapat dilihat dari siswa yang selalu merencanakan jadwal belajar mengenai materi kearsipan sesuai dengan prioritas yang ingin dicapai. Seeking information pada siswa dapat dilihat dari siswa selalu membaca materi kearsipan terlebih dahulu sebelum masuk kelas dan mencari literatur tambahan jika mengalami kesulitan 
belajar. Keeping records and monitoring pada siswa dapat dilihat dari siswa selalu mencatat halhal penting mengenai kearsipan dari penjelasan guru untuk mempermudah dalam memahaminya. Environmental structuring pada siswa dapat dilihat dari siswa telah meninggalkan aktivitas menonton televisi ketika belajar mengenai kearsipan agar bisa memperoleh hasil belajar yang maksimal dan siswa juga belajar di kamar atau tempat yang nyaman agar tidak terganggu dalam belajar. Menurut Permana \& Latifah (2015) menyatakan bahwa proses yang berhasil akan memperlihatkan hasil belajarnya optimal, begitu pula sebaliknya jika proses belajar tidak berhasil maka hasil belajarnya rendah. Self consequating pada siswa dapat dilihat dari siswa yang giat dalam belajar agar nilai ujian mata pelajaran kearsipan mendapatkan nilai yang bagus dan siswa bekerja keras dengan usahanya sendiri agar mendapatkan nilai terbaik dalam ujian. Rehearsing and memorizing pada siswa dapat dilihat dari siswa memahami materi pelajaran kearsipan dengan mengulas kembali tugas yang diberikan guru dan siswa mengerjakan latihan soal pelajaran kearsipan untuk mambantu dalam menghadapi ujian. Seek peer assistance pada siswa dapat dilihat dari siswa yang mengalami kesulitan tugas mengenai materi kearsipan akan meminta bantuan atau berdiskusi dengan temannya. Hamonangan \& Widyarto (2019) menjelaskan bahwa pada saat siswa tidak merasa nyaman belajar, maka siswa akan menemukan kesulitan belajar dalam belajar. Seeking teacher asisstance pada siswa dapat dilihat dari siswa yang mengalami kendala dalam mengikuti pembelajaran kearsipan akan berkonsultasi dengan guru dan siswa yang tidak dapat mengerjakan latihan soal mengenai kearsipan yang diberikan guru akan meminta bantuan guru agar dibimbing.

Sehingga dapat disimpulkan bahwa self regulated learning yang dimiliki siswa sudah baik. Menurut Ruliyanti \& Laksmiwati (2014) dengan siswa memiliki kemampuan self-regulated learning yang bagus disebut dengan self-regulated learner. Hal ini dapat ditunjukkan dengan memiliki strategi organisasi informasi baik dalam menerima materi pelajaran. Self regulated learning yang baik mengharapkan dapat menumbuhkan perasaan diri siswa telah mengatur dirinya terhadap pelajaran khususnya pada mata pelajaran kearsipan sehingga akan berdampak pada naiknya hasil belajar siswa. Hal ini sejalan dengan pendapat Permana \& Latifah (2015) bahwa proses self regulated learning membuat siswa bisa membuat rencana belajar, mengatur tujuan belajar, dan mengevaluasi hasil belajar, sehingga siswa bisa meningkatkan hasil belajarnya. Hasil belajar yang baik dapat diperoleh siswa apabila mampu melaksanakan self regulated learning dengan baik pula.

\section{Pengaruh Self Efficacy terhadap Hasil Belajar Siswa pada Mata Pelajaran Kearsipan di SMK Negeri 10 Surabaya}

Berlandaskan pada uji-t mengetahui nilai sig. sebesar $0.000<0.05$ yang memperlihatkan $\mathrm{H}_{2}$ diterima, hal tersebut bahwa ada pengaruh signifikan self efficacy pada hasil belajar siswa pada mata pelajaran kearsipan di SMK Negeri 10 Surabaya. Penelitian ini sesuai dengan peneliti Nurulwati, Khairina, \& Huda (2020) yang mengutarakan bahwa variabel self efficacy mempengaruhi hasil belajar fisika dilihat dari thitung $>\mathrm{t}$-tabel bernilai $2.878>2.101$. Penelitian Sihaloho, Rahayu, \& Wibowo (2018) yang membuktikan bahwa variabel efikasi diri (self efficacy) berpengaruh positif dan sifnifikan dengam hasil belajar siswa yang pada uji $t$ mempunyai nilai signifikansi $0.000<0.05$. Yulianto (2019) yang mengutarakan variabel self efficacy mempunyai pengaruh pada hasil belajar dimana dapat diketahui jawaban responden $9.09 \%$ dalam kategori cukup baik; $52.77 \%$ kategori baik; dan 38.18\% kategori sangat baik. Rizkiana (2017) pada penelitiannya juga menyatakan bahwa self efficacy berpengaruh dengan hasil belajar mawapres yang signikan dilihatkan dari uji hipotesisi 1 bernilai sig $0,000<0.05$. Penelitian yang dilakukan Rosyida, Utaya, \& Budijanto (2016) mengungkapkan variabel self efficacy mempengaruhi hasil belajar siswa secara signifikan pada uji-t yang bernilai sig $0.000<0.05$. Alminingtias, Soro, \& Handayani (2018) mengutarakan adanya hubungan yang signifikan antara self efficacy dengan hasil belajar matematika siswa yang dilihatkan dari nilai t-hitung lebih besar dari t-tabel yaitu $3.950>1.701$. Penelitian Meiliati, 
Darwis, \& Asdar (2018) juga menyatakan bahwa self efficacy memiliki pengaruh positif yang signifikan pada hasil belajar matematika dengan nilai signifikansi $0.031<0.05$. Namun penelitian ini bertentangan dengan penelitian dilakukan oleh Husna, Budiman, \& Yani (2018) yang mengutarakan tidak ada hubungan yang positif dan siginikan antara self efficacy dengan hasil belajar karena nilai t-hitung lebih besar dari t-tabel yaitu $1.68>0.53$.

Self efficacy yang dimiliki siswa sudah terlihat baik dalam proses pembelajaran kearsipan dan dapat memberikan pengaruh terhadap hasil belajar siswa pada mata pelajaran kearsipan di SMK Negeri 10 Surabaya. Hal ini dilihat dari tingkat evikasi diri (level) pada siswa dimana siswa dapat mengerjakan tugas mengenai materi kearsipan yang sulit dengan kemampuannya, siswa juga optimis menerima semua jenis tugas kearsupan meskipun tugas tersebut dirasa sulit baginya, dan siswa juga bekerja keras mengerjakan tugas kearsipan yang sulit dari guru agar memperoleh hasil yang terbaik. Penelitian Yulianto (2019) menjelaskan apabila siswa mempunyai self efficacy dia akan termotivasi sehingga berhasil mencapainya tujuan belajar serta bisa mempertahankan jika menghadapi kesulitan mengerjakan tugas. Selanjutnya mengenai Generalitas (generality) pada siswa dapat dilihat dari siswa yakin mendapatkan nilai yang bagus karena dapat mengerjakan soal mengenai kearsipan, serta dapat menyelesaikan tugas kearsipan yang diberikan guru, siswa juga yakin dapat memahami materi pada saat pembelajaran kearsipan agar mencapai tujuan belajar yang di inginkan. Menurut Husna, Budiman, \& Yani (2018) bahwa siswa sudah saatnya mencermati self efficacy pada proses belajarnya hingga meningkatkan motivasi agar menjadi lebih aktif serta mempunyai keyakinan tinggi atas kemmapuan dalam belajarnya yang bisa membuat tercapainya tujuan dalam belajar. Mengenai Kekuatan (strength) pada siswa memperlihatkan siswa yang sudah mengerjakan soal ujian dengan percaya diri dan tidak mencontek hasil ujian temannya, siswa juga mengutarakan gagasan materi kearsipan di hadapan guru dan temannya, dan siswa percaya diri pada saat menanggapi pertanyaan guru di kelas. Sihaloho, Rahayu, \& Wibowo (2018) menyampaikan bahwa efikasi diri (self efficacy) berpacu atas keyakinan atau kepercayaan siswa dari kempuannya agar berhasil menjalankan tugas tertentu, mengatasi masalah, serta melakukan tindakan dibutukan sebagai tercapainya tujuan tertentu.

Sehingga dapat disimpulkan bahwasannya self efficacy yaitu salah satu faktor eksternal dari hasil belajar siswa. Berhasilnya siswa diketajui pada saat memperoleh hasil belajar yang bagus pada tingkat self efficacy yang dimilikinnya, oleh sebab itu semakin tinggi self efficacy pada belajar siswa maka bisa memotivasi siswa agar mendapatkan hasil belajar dengan maksimal. Menurut Husna, Budiman, \& Yani (2018), self efficacy memberikan dorongan siswa bertindak maupun berusaha sehingga bisa dinyatakan berhasilnya siswa dipengaruhi oleh self efficacy. Oleh karena itu dengan meningkatkan hasil belajar siswa yang lebih baik maka diperlukan self efficacy yang baik pula.

Pengaruh Self Regulated Learning dan Self Efficacy terhadap Hasil Belajar Siswa pada Mata Pelajaran Kearsipan di SMK Negeri 10 Surabaya

Berdasarkan hasil uji-F mengetahui nilai signifikan $0.000<0.05$ yang menunjukkan bahwa $\mathrm{H}_{3}$ diterima, hal ini bahwasannya terdapat pengaruh signifikan self regulated learning dan self efficacy secara simultan terhadap hasil belajar siswa pada mata pelajaran kearsipan di SMK Negeri 10 Surabaya. Penelitian sejalan dengan Meiliati, Darwis, \& Asdar (2018) menjelaskan bahwa variabel motivasi belajar, self regulated learning, dan self efficacy berpengaruh secara simultan berpengaruh pada hasil belajar matematika dapat terlihat pada uji $\mathrm{f}$ bernilai signifikansi $0.000<0.05$. Menurut Tarumasely (2021) yang mengungkapkan variabel self regulated learning dan self efficacy secara simultan mempengaruhi prestasi akademik mahasiswa pada uji-F dengan nilai sig $0.0001<0.05$. Altun \& Erden (2013) pada penelitiannya mengutarakan ada pengaruh antara strategi pembelajaran berbasis self regulated learning dan persepsi self efficacy dengan prestasi akademik matematika bernilai $\mathrm{p}$ 
$0,01<0.05$. Penelitian Ruliyanti \& Laksmiwati (2014) pada hasil penelitiannya juga memperlihatkan adanya hubungan self regulated learning dan self efficcay pada prestasi akademik siswa dilihat uji-F dengan nilai signifikansinya $0.000<0.05$.

Self regulated learning dan self efficacy yang dimiliki siswa sudah sangat baik dalam mengikuti pembelajaran kearsipan dan dapat memberikan pengaruh terhadap hasil belajar siswa pada mata pelajaran kearsipan di SMK Negeri 10 Surabaya. Siswa harus memiliki self regulated learning dan self efficacy semenjak dini, perilaku ini bisa tumbuh seiring menggunakan normanorma yang dilaksanakan siswa. Self regulated learning dimiliki siswa berharap dapat menumbuhkan perasaan diri siswa untuk mengatur dirinya lebih mandiri terhadap pelajaran di sekolah khususnya pada mata pelajaran kearsipan sehingga akan berdampak pada naiknya hasil belajar kearsipan siswa. Menurut Destiasari, Warneni, \& Syahrudin (2019) mengatakan bahwa selain memperoleh pengetahuan dalam pembelajaran, siswa juga mendapatkan kesempatan untuk mengatur dirinya. Sedangkan untuk self efficacy yang dimiliki siswa akan membuat siswa sanggup menilai keahlian dirinya sendiri, sehingga siswa akan dapat menentukan sikapnya dan sanggup meningkatkan hasil belajarnya. Didukung dengan penelitian Annisa (2017) bahwa self efficacy sebagai keyakinan diri siswa mengetahui sejauh mana kemampuan yang dimilikinnya agar menguasai situasi tertentu yang diingkannya. Sehingga dengan adanya self regulated learning dan self efficacy siswa akan semakin rajin belajar serta dapat meningkatkan kedisiplinan dapat diperoleh dari hasil belajar yang lebih bagus dan optimal. Semakin baik self regulated learning dan self efficacy dimiliki dan diterima oleh siswa, akan meningkatkan hasil belajar siswa yang baik pada mata pelajaran kearsipan.

\section{SIMPULAN DAN REKOMENDASI}

Hasil dan pembahasan, maka dapat disimpulkan sebagai berikut: 1) terdapat pengaruh signifikan self regulated learning terhadap hasil belajar siswa pada mata pelajaran kearsipan di SMK Negeri 10 Surabaya 2) terdapat pengaruh signifikan self efficacy terhadap hasil belajar siswa pada mata pelajaran kearsipan di SMK Negeri 10 $3)$ terdapat pengaruh signifikan self regulated learning dan self efficacy terhadap hasil belajar siswa pada mata pelajaran kearsipan di SMK Negeri 10 Surabaya.

Implikasi dari penelitian ini yang diterapkan di SMK Negeri 10 Surabaya adalah lebih meningkatkan penerapannya dalam self regulated learning karena mampu memberikan arahan yang nantinya siswa bisa mengatur dirinya lebih mandiri dalam kegiatan belajar, serta guru lebih sering memberikan pertanyaan kepada siswa agar tidak cenderung pasif dalam proses pembelajaran agar meningkatkan hasil belajar siswa lebih baik. Sedangkan untuk menerapkan self efficacy di Sekolah SMK Negeri 10 Surabaya juga lebih ditingkatkan lagi karena nantinya akan memotivasi siswa agar lebih percaya diri atas kemampuan yang dimilikinya dalam menghadapi tantangan belajar agar memperoleh hasil belajar yang lebih optimal.

Adapun saran telah diberikan oleh peneliti, yaitu: 1) diharapkan guru dapat meningkatkan self regulated learning dan self efficacy untuk memberikan motivasi siswa agar bisa menetapkan tujuan pembelajarannya yang ingin digapai dan siswa dapat mengerjakan tugas dengan maksimal dan sering berlatih mengerjakan soal yang nantinya melancarkan siswa lebih ringan memahami pelajaran, oleh sebab itu siswa memiliki keyakinan akan kemampuannya dan hasil belajar siswa dapat mengembangkan secara maksimal; 2) menambah variabel lain pada penelitian selanjutnya dengan memakai sampel dan populasi lainnya selain di SMK Negeri 10 Surabaya.

\section{DAFTAR PUSTAKA}

Alminingtias, F. M. N., Soro, S., \& Handayani, I. (2018). Hubungan Self-Efficacy dengan Hasil Belajar Matematika Siswa di MAN 7 Jakarta. Prosiding Seminar Nasional Pendiddikan Matematika UHAMKA, hlm. 365-371, Universitas Muhammdiyah Jakarta.

https://journal.uhamka.ac.id/index.php/se namku/article/view/2725. 
Altun, S. \& Erden, M. (2013). Self-Regulation Based Learning Strategies and Selfefficacy Perceptions as Predictors of Male and Female Students' Mathematics Achievement. Procedia-Social and Behavioral Sciences, 106(1), 2354-2364. https://doi.org/https://doi.org/10.1016/j.sb spro.2013.12.270.

Annisa, V. (2017). Pengaruh Self Efficacy terhadap Hasil Belajar Dasar-dasar Akuntansi di SMKN 1 Pontianak. Jurnal Pendidikan dan Pembelajaran Khatulistiwa, 6(7), 110.

https://jurnal.untan.ac.id/index.php/jpdpb/ article/view/20875/16975.

Anurrahman. (2014). Belajar dan Pembelajaran. Bandung: Alfabeta.

Arfani, L. (2016). Mengurai Hakikat Pendidikan, Belajar dan Pembelajaran. Jurnal Pendidikan Pancasila dan Kewarganegaraan dan Hukum, 11(2), 8197.

https://pbpp.ejournal.unri.ac.id/index.php/ JPB/article/view/5160/4838.

Aryani, T. D., \& Hasyim, M. (2018). Pengaruh Kecemasan Matematis, Problem Stress Matematika Dan Self-Regulated Learning Terhadap Hasil Belajar Matematika Siswa. Jurnal Pendidikan Matematika FKIP Universitas Muhammadiyah Metro, $7(2)$, 243-252. https://pdfs.semanticscholar.org/a8f0/c06 7b4c55020b32de08c53ffc4d7a97aa7a1.p df

Asri, K. Z., Witono, A. H., \& Affandi, L. M. (2020). Pengaruh Ekspektasi Guru Dan Self-Efficacy Siswa Terhadap Hasil Belajar Pada Siswa Kelas V Di Sd Gugus V Cakranegara Tahun Pelajaran 2019/2020. Jurnal Ilmiah Pendas, 1(1), $19-25$.

http://journal.unram.ac.id/index.php/jiwp $\mathrm{p} /$ article/view/51

Astutik, S. M. \& Wasiti. (2016). Pengaruh Self Regulated Learning dan Ketersediaan Fasilitas Belajar terhadap Hasil Belajar Siswa pada Mata Pelajaran Otomatisasi Perkantoran. Jurnal Pendidikan Bisnis dan Manajemen, 2(1), 50-57. http://journal2.um.ac.id/index.php/jpbm/a rticle/view/1690.

Cintya, A. N. D. \& Nugraha, J. (2020). Pengaruh Sarana Prasarana dan Motivasi Belajar terhadap Hasil Belajar Siswa Kelas XII Otomatisasi Tata Kelola Perkantoran di SMK Ketintang Surabaya. Jurnal Pendidikan Administrasi Perkantoran (JPAP), $\quad$ 9(1), 1-16. https://journal.unesa.ac.id/index.php/jpap/ article/view/8866.

Destiasari, R., Warneni., \& Syahrudin, H. (2019). Pengaruh Self Regulated Learning terhadap Hasil Belajar Siswa di SMK. Jurnal Pendidikan dan Pembelajaran Khatulistiwa, $\quad 8(12), \quad 1-8$. https://jurnal.untan.ac.id/index.php/jpdpb/ article/view/37897.

Fasikhah, S. S. \& Fatimah, S. (2013). Self Regulated Learning (SRL) dalam Meningkatkan Prestasi Akademik pada Mahasiswa. Jurnal Ilmiah Psikologi Terapan, 1(1), 145-155. http://ejournal.umm.ac.id/index.php/jipt/a rticle/view/1364.

Fitria, V. \& Handayani, I. (2020). Kemampuan Komunikasi Matematis Berdasarkan Self Efficacy. Jurnal Matematika dan Matematika, 4(1), 189-202. https://ejournal.unibabwi.ac.id/index.php/ transformasi/article/view/906.

Ghozali, I. (2013). Aplikasi Analisis Multivariate dengan Program IBM SPSS 20. Semarang: Badan Penerbit Universitas Diponegoro.

Gujarati, D. N. (2012). Dasar - Dasar Ekonometrika, Terjemahan Mangunsong, R.C. Jakarta : Salemba Empat.

Gunawan, W. E., Nuridja, I. M., \& Suharsono, N. (2014). Pengaruh Pengalaman Prakerin terhadap Minat Berwirausaha Siswa Kelas XI Jurusan Pemasaran SMKN 1 Klungkung 2012/2013. Jurnal Pendidikan Ekonomi Undiksha, 4(1), 1-12. https://ejournal.undiksha.ac.id/index.php/ JJPE/article/view/2071.

Hamidy, A. \& Merliza, P. (2019). The Influence Of Achievement Motivation And Self- 
Regulated Learning (SRL) On Students' Matematics Learning Outcomes. Jurnal Penelitian Pendidikan Dan Pembelajaran, 6(2) 27-39. https://journal.iainsamarinda.ac.id/index.php/Tarbiyawat/art icle/view/20

Hamonangan, R. H. \& Widyarto, S. (2019). Pengaruh Self Regulated Learning dan Self Control terhadap Hasil Belajar Bahasa Indonesia. Jurnal Dimensi Pendidikan dan Pembelajaran, $\quad 7(1), \quad$ 5-10. http://journal.umpo.ac.id/index.php/dime nsi/article/view/1056.

Handayani, T. P. (2020). Self Efficacy dan Motivasi terhadap Hasil Belajar Mahasiswa Kebidanan pada Mata Kuliah Asuhan Persalinan. Jurnal Kebidanan, 6(1), 132-140. http://www.ejurnalmalahayati.ac.id/index. php/kebidanan/article/view/2185.

Hardianto, G., Erlamsyah, \& Nurfarhanah. (2014). Hubungan Antara Self Efficacy Akademik Dengan Hasil Belajar Siswa. Jurnal KONSELOR, 3(1), 17.http://ejournal.unp.ac.id/index.php/kons elor/article/view/2978.

Husna, R., Budiman., \& Yani, B.S. (2018). Pengaruh Self Efficacy terhadap Hasil Belajar Matematika Siswa di Kelas X SMK SMTI Banda Aceh. Jurnal Ilmiah Mahasiswa Pendidikan Matematika, 3(2), 43-38.

http://www.jim.unsyiah.ac.id/pendidikan matematika/article/view/5136.

Indrayanto, M. Q. (2018). Pengaruh Self Regulated Learning terhadap Hasil Belajar Bahasa Arab Siswa SMA Negeri 20 Gowa. Jurnal Shaut Al-'Arabiyah, 6(2), 142-154. http://103.55.216.56/index.php/ShautulArabiyah/article/view/7125.

Komara, E. (2014). Belajar dan Pembelajaran Interaktif. Bandung: Refika Aditama.

Mayanto, A. (2020). Pengaruh lokus pengendalian, efikasi diri, dan keterampilan diri terhadap hasil belajar pendidikan jasmani. Journal of Physical Activity, 1(2), 73-83. https://journal.apopi.org/index.php/jpa/art icle/view/16
Meiliati, R., Darwis, M., \& Asdar. (2018). Pengaruh Motivasi Belajar, Self Efficacy, dan Self Regulated Learning terhadap Hasil Belajar Matematika. Issues in Mathematics Education, 2(1), 83-91. https://ojs.unm.ac.id/imed/article/view/94 84.

Monika \& Adman. (2017). Peran Efikasi Diri dan Motivasi Belajar dalam Meningkatkan Hasil Belajar Siswa Sekolah Menengah Kejuruan. Jurnal Pendidikan Manajemen Perkantoran, 2(2), 219-226. https://ejournal.upi.edu/index.php/jpmanp er/article/view/8111.

Nurhasanah, S. (2017). Praktikum 2 untuk Ekonomi dan Bisnis Aplikasi Ms Excel dan SPSS. Salemba Empat.

Nurulwati, N., Khairinia, L., \& Huda, I. (2020). The effect of students self-efficacy on the learning outcomes in learning physics. Journal of Physics: Conference Series, 1460(1-4).

https://iopscience.iop.org/article/10.1088/ 1742-6596/1460/1/12113/meta

Pane, A. \& Dasopang, M. D. (2017). Belajar dan Pembelajaran. Jurnal Kajian Ilmu-ilmu Keislaman, 03(2), 333-352. $\mathrm{http}: / /$ jurnal.iain-

padangsidimpuan.ac.id/index.php/F/articl e/view/945/795.

Permana, H. A. \& Latifah, L. (2015). Pengrauh Self Regulated Learning Lingkungan Keluarga dan Disiplin Belajar terhadap Hasil Belajar Mata Pelajaran Pengantar Akuntansi Kelas Akuntansi SMK PL Tarcisius Semarang Tahun Ajaran 2014/2015. Economic Education Analysis Journal, 4(3), 789802.

https://journal.unnes.ac.id/sju/index.php/e eaj/article/view/8520.

Purwanto. (2009). Evaluasi Hasil Belajar. Surakarta: Pustaka Belajar.

Puspasari, D. \& Puspasari, D. (2019). Development of Student Worksheet Based on Problem Based Learning in Office Management Subject. International Journal of Educational Research Review, 4(3), 
http://www.ijere.com/frontend//articles/p df/v4i3/journal-durinta-puspasari-anddurinda-puspasaripdfpdf.pdf.

Puspitasari, Z. \& Margunani. (2017). Self Efficacy Memediasi Pengaruh Kondisi Sosial Ekonomi Orang Tua dan Lingkungan Sekolah terhadap Hasil Belajar Ekonomi. Economic Education Analysis Journal, $6(3)$, 763-776. https://journal.unnes.ac.id/sju/index.php/e eaj/article/view/20286.

Putra, I. K. A. D., Arini, N. W., \& Sudarma, I. K. (2019). Pengaruh Model Self Regulated Learning terhadap Hasil Belajar IPA Siswa. International Journal of Elementary Education, 3(3), 258-266. https://ejournal.undiksha.ac.id/index.php/ IJEE/article/view/19406.

Rahmatika, F. \& Susilowibowo, J. (2016). Pengaruh Penguasaan Akuntansi Dasar, Kosa Kata Bahasa Inggris Akuntansi dan Efikasi Diri terhadap Hasil Belajar Komputer Akuntansi MYOB Siswa Kelas XI Akuntansi SMK Negeri 2 Buduran Sidoarjo. Jurnal Pendidikan Akuntansi, 4(3), 1-7. https://jurnalmahasiswa.unesa.ac.id/index .php/jpak/article/view/32739.

Ranti, M. G., Budiarti, I., \& Trisna, B. N. (2017). Pengaruh Kemandirian Belajar (Self Regulated Learning) terhadap Hasil Belajar Mahasiswa pada Matakuliah Struktur Aljabar. Jurnal Pendidikan Matematika, 3(1), 75-83. https://core.ac.uk/download/pdf/2954164 03.pdf.

Respita, R. (2020). Pengaruh Gaya Belajar dan Self-Efficacy terhadap Hasil Belajar Siswa. Journal of Multidisciplinary Research and Development, 2(3), 67-75. https://jurnal.ranahresearch.com/index.ph $\mathrm{p} / \mathrm{R} 2 \mathrm{~J} / \mathrm{article} / \mathrm{view} / 362$.

Reynold, W. M. \& Miller, G.E. (2003). Handbook of Psychology. United States of America: Simultaneously In Canada.

Rizkiana, A. (2017). Pengaruh Self Efficacy terhadap Hasil Belajar Mahasiswa Berprestasi (MAWAPRES) SKIP PGRI
Bangkalan. Jurnal Ilmiah Ekonomi dan Pembelajarannya, 5(2), 117-122. http://ejournal.unipma.ac.id/index.php/equilibriu $\mathrm{m} /$ article/view/1538.

Rosyida, F., Utaya, S., \& Budijanto. (2016). Pengaruh Kebiasaan Belajar dan Self Efficacy terhadap Hasil Belajar Geografi di SMA. Jurnal Pendidikan Geografi, 21(2), $17-28$ http://journal.um.ac.id/index.php/pendidi kan-geografi/article/view/5903.

Ruliyanti, B. D. \& Laksmiwati, H. (2014). Hubungan Antara Self-Efficacy dan SelfRegulated Learning dengan Prestasi Akademik Matematika Siswa SMAN 2 Bangkalan. Jurnal Penelitian Psikologi, 3(2), 1-7. https://jurnalmahasiswa.unesa.ac.id/index .php/character/article/view/10976.

Rustam, A. \& Wahyuni, D. S. (2020). Pengaruh Efikasi Diri Dan Regulasi Diri Terhadap Hasil Belajar Matematka Siswa Kelas X Sma Alkhairaat 1 Palu. Jurnal Pendidikan Dan Pembelajaran, 3(1), 61-68. https://unisa-palu.ejournal.id/gurutua/article/view/48

Sihaloho, L., Rahayu, A., \& Wibowo, L.A. (2018). Pengaruh Efikasi Diri (Self Efficacy) terhadap Hasil Belajar Ekonomi Siswa Kelas XI IPS SMA Negeri Se-Kota Bandung. Jurnal Inovasi Pembelajaran, 4(1), 62-70. http://202.52.52.22/index.php/jinop/articl e/view/5671.

Situmorang, E., Hutasuhut, S., \& Maipita, I. (2019). The Effect of E-Learning, Student Facilitator and Explaining Model Learning and Self-Regulated Learning on 11th Grade Students Learning Outcomes of Economic Subject in Senior High School 1 Perbaungan School Year 2019/2020. Budapest International Research and Critics in Linguistics and Education, 2(4), 261-469. http://bircujournal.com/index.php/birle/article/view/ 537.

Sucipto. (2014). Pengaruh Self-Regulated Learning dan Dukungan Orang Tua 
terhadap Hasil Belajar Peserta Didik pada Mata Pelajaran Ekonomi Program Studi IPS SMA Negeri di Kota Jombang. Jurnal Ekonomi Pendidikan dan Kewirausahaan, 2(2), 237-251. https://journal.unesa.ac.id/index.php/jepk/ article/view/733.

Sugiyono. (2019). Metode Penelitian Kuantitatif Kualitatif dan $R \& D$. Bandung: Alfabeta.

Suherman, D. P., Purwaningsih, W., \& Diana, S. (2018). Analisis Hubungan Self-efficacy dan Metakognitif terhadap Hasil Belajar Siswa SMA Berdasarkan Gender pada Konsep Genetika. Indonesian Journal of Biology Education, 1(1), 14-20. https://ejournal.upi.edu/index.php/asimila si/article/view/11450.

Tarumasely, Y. (2021). Pengaruh Self Regulated Learning Dan Self Efficacy Terhadap Prestasi Akademik Mahasiswa. Jurnal Pendidikan Edutama, 8(1), 71-80. https://ejurnal.ikippgribojonegoro.ac.id/in dex.php/JPE/article/view/1359

Tarumasely, Y. (2020). Pengaruh Strategi Pembelajaran Berbasis Self Regulated Learning dan Pengetahuan Awal terhadap Hasil Belajar. Jurnal Pendidikan Agama Kristen, VI(2), 98-110. http://ejournal.iaknambon.ac.id/index.php/IT/arti cle/view/239.

Undang-undang Republik Indonesia Nomor 20 Tahun 2003 Tentang Sistem Pendidikan Nasional.

Wahyuningtyas, N. \& Febrianingsih, L. (2018). Pengaruh Self Efficacy dan Motivasi terhadap Hasil Belajar Matematika Siswa. Jurnal Pendidikan dan Pembelajaran Matematika, 4(1), 38-46. http://jurnal.stkippgritulungagung.ac.id/in dex.php/jp2m/article/view/1777.

Wilanda, R. A. \& Supriyono. (2014). Penerapan Model Pembelajara Langsung untuk Meningkatkan Hasil Belajar pada Tema Peristiwa di Sekolah Dasar. Jurnal Penelitian Pendidikan Guru Sekolah Dasar, 2(3), 1-10. https://jurnalmahasiswa.unesa.ac.id/index .php/jurnal-penelitianpgsd/article/view/12218.

Yulianto, A. (2019). Pengaruh Self Efficacy terhadap Hasil Belajar Ekonomi Siswa SMA. Jurnal Pendidikan Ilmu Pengetahuan Sosial Indonesia, 4(1), 8-12. https://journal.stkipsingkawang.ac.id/inde x.php/JurnalPIPSI/article/view/1099.

Zimmerman, B. J. (2000). Self Efficacy: an Essential Motive to Learn. Contemporary Educational Psychology, 25(1), 82-91. https://www.sciencedirect.com/science/ar ticle/pii/S0361476X99910160. 